\title{
ANALISIS MISKONSEPSI SISWA KELAS X PADA MATERI GERAK
}

\author{
Ovilia Putri Utami Gumay \\ zhoulia127@gmail.com
}

Program Studi Pendidikan Fisika STKIP PGRI Lubuklinggau, Sumatera Selatan, Indonesia
Received: 29 Mei 2021
Revised: 30 Mei 2021
Accepted: 16 Juni 2021

\begin{abstract}
This research is motivated by problems that researchers obtained through library that research on physics misconceptions especially on a straight motion kinematics matter much done both domestically and abroad, but these studies have not been done in SMA Negeri Terawas environment. One of the problems misconceptions related to the problem students in the class $X$ SMA Negeri Terawas is the low learning outcomes of students on the subject of motion kinematics straight. The purpose of this study was to determine the form of misconceptions experienced by $X$ grade students, the low learning outcomes, especially on the subject of motion kinematics straight. This research is a descriptive method. Data collection techniques using multiple choice tests are the reasons, and the level of confidence (CRI). The subjects were taken through purposive sampling technique. From the analysis of students' responses, it was found that of the 14 items were presented, there are 7 items that indicate the occurrence miskonsepsi on students, 2 items showed lack of students to understand the concept, and 5 items showed a good mastery of concepts by students. Number of students who have reached $100 \%$ for the misconceptions about the number 13 with an average high CRI is 4.74, and about the number 14 with an average of 4.76 CRI. The misconception occurs in sub subject matter motion free fall .
\end{abstract}

Abstrack : Misconceptions, Certainty of Response Index (CRI), Motion, Kinematics

Abstrak: Penelitian ini dilatarbelakangi oleh permasalahan yang peneliti peroleh melalui perpustakaan bahwa penelitian tentang miskonsepsi fisika khususnya pada materi kinematika gerak lurus banyak dilakukan baik di dalam negeri maupun di luar negeri, namun penelitian tersebut belum pernah dilakukan di lingkungan SMA Negeri Terawas. Salah satu masalah miskonsepsi yang terkait dengan masalah siswa kelas X SMA Negeri Terawas adalah rendahnya hasil belajar siswa pada mata pelajaran kinematika gerak. Tujuan penelitian ini adalah untuk mengetahui bentuk miskonsepsi yang dialami siswa kelas X, rendahnya hasil belajar khususnya pada mata pelajaran kinematika gerak. Penelitian ini merupakan metode deskriptif. Teknik pengumpulan data menggunakan tes pilihan ganda yaitu alasan, dan tingkat kepercayaan (CRI). Subjek diambil dengan teknik purposive sampling. Dari hasil analisis respon siswa ditemukan bahwa dari 14 item yang disajikan terdapat 7 item yang menunjukkan terjadinya miskonsepsi pada siswa, 2 item menunjukkan siswa kurang memahami konsep, dan 5 item menunjukkan penguasaan konsep yang baik oleh siswa. Jumlah siswa yang sudah mencapai 100\% kesalahpahaman soal angka 13 dengan rata-rata CRI tinggi tersebut 4,74, dan tentang angka 14 dengan rata-rata 4,76 CRI. Kesalahpahaman terjadi pada sub pokok bahasan gerak jatuh bebas.

Kata kunci: Miskonsepsi, Certainty of Response Index (CRI), Gerak, Kinematika

\section{PENDAHULUAN}

Salah satu kompetensi yang harus dimiliki oleh setiap calon guru fisika salah satunya adalah kompetensi materi ajar yang akan diajarkan kepada siswa. Kompetensi terhadap materi ajar sangatlah erat dengan pemahaman konsep. Seorang calon guru akan lebih mudah 
untuk merancang metode atau strategi pembelajaran ketika pemahaman terhadap konsepnya baik. Kenyataannya, masih banyak calon guru yang tidak tahu konsep, atau miskonsepsi mengenai konsep yang akan diajarkannya (Gumilar, S, 2016). Dalam proses pembelajaran disekolah tugas utama seorang guru ialah mengajar sedangkan tugas siswa ialah belajar tujuan belajar adalah untuk mendapatkan pengetahuan, penanaman konsep dan keterampilan, dan pembentukan sikap (Trisna, N., \& Ariani, T, 2019).

Miskonsepsi merupakan faktor penting yang mempengaruhi pemahaman siswa untuk memahami suatu konsep. Hal ini menyebabkan pentingnya mengetahui miskonsepsi yang dimiliki oleh siswa. Ada banyak metode yang dapat digunakan untuk mengetahui pemahaman konsep dan miskonsepsi. Ada beberapa metode yang biasa digunakan untuk mengetahui pemahaman konsep dan miskonsepsi siswa, yaitu berupa pertanyaan terbuka, two-tier diagnostik test, peta konsep, prediction-observation-explanation, wawancara mengenai suatu kejadian atau peristiwa, wawancara mengenai konsep, word association dan menggambar (Suwarna, I. P, 2013).

Ilmu fisika memiliki peran penting dalam perkembangan ilmu pengetahuan dan teknologi. Mengingat begitu penting peran ilmu fisika, maka sudah semestinya ilmu fisika dipahami dengan baik oleh siswa yang mempelajari fisika. Upaya siswa dalam mempelajari fisika sering menemui hambatan-hambatan yang disebabkan adanya anggapan bahwa fisika sebagai pelajaran yang sulit dipahami, dan didukung oleh pengajaran fisika yang tidak menarik. Para peneliti bidang pendidikan fisika di Indonesia menyebutkan beragam alasan mengenai kurangnya pemahaman fisika siswa. Banyak pihak mengatakan bahwa salah satu penyebab kurangnya pemahaman fisika siswa adalah terjadinya miskonsepsi (Novitasari, F., Supriadi, B., \& Maryani, M, 2019).

Miskonsepsi bisa terjadi pada semua bidang sains, seperti fisika, biologi, kimia, dan astronomi. Tidak ada bidang yang dikecualikan dari miskonsepsi. Dalam bidang fisika, miskonsepsi meliputi hampir semua subbidang yang ada, salah satunya pada materi gerak lurus (Suparno, 2013). Materi gerak lurus diajarkan berulang-ulang pada setiap jenjang pendidikan dan merupakan syarat agar bisa masuk ke materi selanjutnya yaitu mengenai gerak melingkar. Berdasarkan Kurikulum Tingkat Satuan Pendidikan, konsep gerak dikenalkan pada siswa SD tepatnya pada kelas VI semester 2. Pada jenjang berikutnya yaitu SMP konsep gerak diajarkan pada kelas VII semester II, sedangkan pada SMA dipelajari di kelas X semester I. kemudian konsep tersebut dikembangkan lagi pada mata kuliah mekanika di perguruan tinggi. 
Dalam menganalisis miskonsepsi, terdapat persoalan yang tidak dapat diabaikan yaitu masalah pengidentifikasian terjadinya miskonsepsi. Hingga saat ini masih terdapat kesulitan dalam membedakan antara siswa yang miskonsepsi dan tidak tahu konsep. Ada beberapa cara yang dapat digunakan untuk mengidentifikasi miskonsepsi siswa diantaranya tes multiple choice dengan reasoning terbuka. Dalam tes tersebut siswa tidak hanya memilih jawaban yang disediakan, tetapi mereka juga harus menulis alasan mengapa mereka memilih jawaban tersebut (Suparno,2013). Untuk mengidentifikasi terjadinya miskonsepsi, sekaligus dapat membedakannya dengan siswa yang tidak tahu konsep telah dikembangkan suatu metode identifikasi yang dikenal dengan istilah Certainty of Response Index (CRI). Dengan CRI akan dapat diungkap perbandingan miskonsepsi kelas lucky guess, a luck of knowledge, miskonsepsi, dan benar-benar memahami konsep. Selanjutnya dari hasil analisis tes multiple choice dengan reasoning terbuka yang dilengkapi CRI dapat ditentukan faktor-faktor penyebab miskonsepsi siswa dan solusi untuk mengatasi miskonsepsi. Syuhendri (2014) menjelaskan bahwa CRI merupakan instrumen yang baik digunakan untuk membedakan konsepsi seseorang, apakah memiliki konsepsi yang benar, kurang pengetahuan atau mengalami miskonsepsi.

Suparno (2013) mengemukakan bahwa dari 700 studi mengenai miskonsepsi bidang fisika, lebih dari 300 yang meneliti tentang miskonsepsi pada pokok bahasan mekanika yang merupakan induk dari cabang ilmu kinematika. Berdasarkan data yang peneliti peroleh, penelitian tentang miskonsepsi siswa belum pernah dilakukan di lingkungan SMA Negeri Terawas. Peneliti melakukan observasi awal di SMA Negeri Terawas dengan mewawancarai guru fisika yang mengajar di kelas $X$ untuk mencari sumber data yang dapat dijadikan sebuah acuan untuk melakukan penelitian mengenai miskonsepsi. Pada wawancara tersebut, beliau mengatakan bahwa nilai Ulangan Akhir Semester Gasal siswa kelas X meraih nilai yg kurang memuaskan. Hal tersebut ditunjukkan dengan persentase ketuntasan yang hanya mencapai $64 \%$. Selain itu beliau juga menyatakan bahwa pada Ulangan Harian ke-2 semester Gasal dari seluruh siswa kelas X, khususnya pada pokok bahasan Kinematika yang salah satu materinya mengenai gerak menunjukkan hasil yang sedikit mengecewakan pada siswa kelas X. Hal ini ditunjukkan dengan persentase ketuntasan yang hanya mencapai 62,5\%, Masalah di atas pada SMA Negeri Terawas merupakan suatu masalah yang tidak biasa. Guru tersebut memiliki pandangan bahwa tidak tercapainya ketuntasan belajar menurut standar persentase yang ditetapkan oleh pihak sekolah salah satu faktornya disebabkan karena adanya miskonsepsi yang di 
alami oleh siswa. Pendapat tersebut juga sesuai dengan yang dikemukakan oleh Klammer (dalam Nopviana, 2011), bahwa terhambatnya proses penerimaan dan asimilasi pengetahuan-pengetahuan baru dalam diri siswa yang dapat menghalangi keberhasilan siswa dalam proses belajar lebih lanjut, salah satu faktornya disebabkan oleh adanya misksonsepsi. Berdasarkan permasalahan yang telah diuraikan di atas, peneliti tertarik untuk mengadakan penelitian dengan judul “Analisis Miskonsepsi Siswa Kelas X pada Materi Gerak”.

\section{METODE PENELITIAN}

1. Rancangan Penelitian

Penelitian ini menggunakan metode deskriptif, karena data yang dideskripsikan dan dianalisis seperti apa adanya sesuai dengan data yang ditemukan pada saat penelitian ini dilakukan dilokasi penelitian.

\section{Subyek Penelitian}

Subyek penelitian dalam penelitian ini adalah siswa di kelas X SMA Negeri Terawas tahun pelajaran 2019/2020 dengan jumlah 42 siswa, yang terdiri dari 20 siswa laki-laki dan 22 siswa perempuan. Subyek penelitian diambil berdasarkan teknik purposive sampling. Teknik purposive sampling merupakan teknik pengambilan sampel berdasarkan tujuan

\section{Teknik Pengumpulan Data}

Dalam penelitian ini teknik pengumpulan data dikumpulkan melalui tes. Tes yang digunakan dalam penelitian ini adalah tes multiple choice dengan reasoning terbuka dilengkapi dengan indeks keyakinan (CRI). Butir soal tes disusun berupa soal berbentuk pilihan ganda dengan 5 option pilihan yang harus diberi alasan, dan dibubuhi indeks keyakinan $(C R I)$.

\section{Teknik Analisis Data}

Dalam penelitian ini, analisis data dilakukan pada hasil jawaban siswa yang diperoleh melalui tes multiple choice dengan reasoning terbuka yang dilengkapi CRI. Langkahlangkah menganalisis data hasil penelitian adalah sebagai berikut:

a. Mencari rata-rata $C R I$ jawaban benar dan $C R I$ jawaban salah dengan rumus berikut:

$$
R_{b}=\frac{\sum C R I_{b}}{n_{b}} \text { dan } R_{s}=\frac{\sum C R I_{s}}{n_{s}}
$$

b. Menentukan fraksi siswa yang menjawab benar atau fraksi siswa yang 
menjawab salah dari total seluruh siswa, dengan persamaan sebagai berikut:

$f_{b}=\frac{n_{b}}{T}$ atau $\quad f_{s}=\frac{n_{s}}{T}$

$f_{b}=$ fraksi siswa yang menjawab benar dari total siswa

$n_{b}=$ jumlah siswa yang menjawab benar

$f_{s}=$ fraksi siswa yang menjawab salah dari total siswa

$n_{s}=$ jumlah siswa yang menjawab salah

$\mathrm{T}=$ jumlah total siswa.

(Hasan, S., Bagayoko, D., \& Kelley, E. L, 1999)

\section{HASIL DAN PEMBAHASAN}

Analisis data tes dilakukan dengan cara mencari rata-rata CRI jawaban benar dan CRI jawaban salah pada setiap konsep gerak yang diujikan. Berdasarkan hasil analisis data, siswa mengalami miskonsepsi atau tidak (tahu konsep atau tidak tahu konsep) dalam menjawab setiap soal tes yang diberikan dapat diketahui dengan melakukan perbandingan antara rata-rata $C R I$ jawaban benar dan rata-rata $C R I$ jawaban salah untuk setiap soal, serta fraksi siswa untuk jawaban benar dan fraksi siswa untuk jawaban salah. Perbandingan antara rata-rata $C R I$ dan fraksi siswa yang menjawab benar dan rata-rata $C R I$ dan fraksi siswa yang menjawab salah. Sehingga jika dihubungkan dapat kita lihat pada di bawah ini.

Tabel 1. Rata-rata $C R I$ dan Fraksi Siswa Menjawab Benar dan Rata-rata $C R I$ dan Fraksi Siswa Menjawab Salah

\begin{tabular}{|c|c|c|c|c|c|c|}
\hline \multirow{2}{*}{\multicolumn{2}{|c|}{ Konsep Gerak Lurus }} & \multirow{2}{*}{$\begin{array}{l}\text { No. } \\
\text { Soal }\end{array}$} & \multicolumn{2}{|c|}{$\begin{array}{c}\text { Siswa } \\
\text { yang }\end{array}$} & \multicolumn{2}{|c|}{$\begin{array}{c}\text { Siswa } \\
\text { yang }\end{array}$} \\
\hline & & & $C R I$ & Fraksi & $C R I$ & Fraksi \\
\hline \multirow{2}{*}{\multicolumn{2}{|c|}{$\begin{array}{l}\text { Jarak dan perpindahan } \\
\text { Kelajuan rata-rata dan } \\
\text { kecepatan rata-rata }\end{array}$}} & 1 & 4,83 & 0,36 & 4,42 & 0,64 \\
\hline & & 2 & 3,46 & 0,30 & 4,82 & 0,70 \\
\hline \multirow{7}{*}{ GLB } & Definisi GLB & 3 & 4,94 & 0,92 & 4,33 & 0,08 \\
\hline & Persmaan GLB & 4 & 4,95 & 1,00 & 0,00 & 0,00 \\
\hline & Definisi GLBB & 5 & 4,92 & 1,00 & 0,00 & 0,00 \\
\hline & & 6 & 4,75 & 0,19 & 4,66 & 0,81 \\
\hline & & 7 & 4,77 & 0,83 & 3,57 & 0,17 \\
\hline & Persamaan & 8 & 4,67 & 0,14 & 1,03 & 0,86 \\
\hline & ULBБ & 9 & 4,66 & 0,28 & 0,66 & 0,72 \\
\hline \multirow[t]{5}{*}{ GLB B } & & 10 & 4,92 & 1,00 & 0,00 & 0,00 \\
\hline & $\begin{array}{l}\text { Penerapan } \\
\text { GLBB }\end{array}$ & 11 & 2,36 & 0,33 & 4,40 & 0,67 \\
\hline & $\begin{array}{l}\text { Gerak vertikal } \\
\text { ke atas }\end{array}$ & 12 & 4,00 & 0,14 & 4,27 & 0,86 \\
\hline & Gerak jatuh & 13 & 0,00 & 0,00 & 4,74 & 1,00 \\
\hline & Bebas & 14 & 0,00 & 0,00 & 4,76 & 1,00 \\
\hline
\end{tabular}


Pada di atas menunjukkan perbandingan rata-rata $C R I$ jawaban benar dan fraksi siswa untuk jawaban benar dan hubungan rata-rata $C R I$ jawaban salah dengan fraksi siswa yang menjawab salah. Untuk menentukan apakah siswa mengalami miskonsepsi, tahu konsep, dan tidak tahu konsep dapat dilihat pada tabel 1.

Pada soal nomor 1 (konsep jarak dan perpindahan), rata-rata $C R I$ jawaban benar adalah 4,83, dan untuk rata-rata $C R I$ jawaban salah 4,42. Untuk fraksi siswa menjawab salah (0,64 atau 64\%) lebih besar dari fraksi siswa menjawab benar (0,36 atau 36\%). Berdasarkan tabel 2.2, rata-rata $C R I$ jawaban salah tinggi $(>2,5)$ menandakan siswa mengalami miskonsepsi. Hal ini diperkuat oleh persentase seluruh siswa yang menjawab salah (64\%) lebih besar dari persentase siswa menjawab benar. Sehingga secara keseluruhan dapat disimpulkan bahwa siswa mengalami miskonsepsi pada soal nomor 1 .

Dengan cara yang sama seperti penjelasan nomor 1, untuk soal nomor 2 (konsep kelajuan rata-rata dan kecepatan rata-rata) rata-rata $C R I$ jawaban benar adalah 3,46, dan rata-rata $C R I$ jawaban salah adalah 4,82 . Untuk fraksi siswa menjawab benar $(0,30$ atau $30 \%)$ lebih kecil dari fraksi siswa yang menjawab salah (0,70 atau $70 \%)$. Karena persentase siswa yang menjawab salah lebih besar dari persentase siswa yang menjawab benar, dan rata-rata $C R I$ jawaban salah tinggi (>2,5) maka menandakan siswa mengalami miskonsepsi. Sehingga secara keseluruhan dapat disimpulkan bahwa siswa mengalami miskonsepsi pada soal nomor 2.

Untuk soal nomor 3 (konsep definisi GLB) rata-rata $C R I$ jawaban benar adalah 4,95 dan untuk rata-rata $C R I$ jawaban salah adalah 4,33. Fraksi siswa yang menjawab benar (0,92 atau 92\%) lebih besar dari fraksi siswa yang menjawab salah (0,08 atau 8\%). Pada soal ini dapat dikatakan bahwa siswa memahami konsep dengan baik, hal ini diperkuat oleh persentase siswa yang menjawab benar sebesar 92\% dengan rata-rata $C R I$ jawaban benar tinggi $(>2,5)$.

Pada soal nomor 4 (konsep persamaan GLB) rata-rata $C R I$ jawaban benar adalah 4,95 dan rata-rata $C R I$ jawaban salah adalah 0,00. Fraksi siswa yang menjawab benar adalah 1,00 atau $100 \%$ yang menandakan bahwa tidak ada siswa yang menjawab salah. Sehingga dapat dikatakan pada soal ini semua siswa memahami konsep dengan baik dengan rata-rata CRI jawaban benar tinggi $(>2,5)$. Begitupun pada soal nomor 5 (konsep definisi GLBB) semua siswa memahami konsep dengan baik, hal ini ditunjukkan dengan fraksi siswa yang menjawab benar mencapai $100 \%$ dengan rata-rata $C R I$ jawaban benar tinggi yaitu 4,92 .

Puplished at https://ojs.stkippgri-lubuklinggau.ac.id/index.php/SJPIF 
Pada soal nomor 6 (konsep persamaan GLBB) rata-rata CRI jawaban benar adalah 4,75 dan rata-rata $C R I$ jawaban salah adalah 4,66. Sedangkan fraksi siswa yang menjawab benar (0,19 atau $19 \%)$ lebih kecil dari fraksi siswa yang menjawab salah $(0,81$ atau $81 \%$ ). Sehingga pada soal ini secara keseluruhan dapat disimpulkan bahwa siswa mengalami miskonsepsi dengan rata-rata $C R I$ jawaban salah tinggi $(>2,5)$.

Untuk soal nomor 7 (konsep persamaan GLBB) rata-rata CRI jawaban benar adalah 4,77 dan rata-rata $C R I$ jawaban salah adalah 3,57. Fraksi siswa yang menjawab benar $(0,83$ atau $83 \%)$ lebih besar dari fraksi siswa yang menjawab salah $(0,17$ atau $17 \%)$. Maka pada soal ini secara keseluruhan dapat dikatakan siswa memahami konsep dengan baik.

Pada soal nomor 8 (konsep persamaan GLBB) rata-rata $C R I$ jawaban benar adalah 4,67 dan rata-rata $C R I$ jawaban salah adalah 1,03. Sedangkan fraksi siswa yang menjawab benar $(0,14$ atau $14 \%)$ lebih kecil dari persentase siswa yang menjawab salah $(0,86$ atau 86\%). Maka dapat disimpulkan bahwa secara keseluruhan siswa tidak memahami konsep (tidak tahu konsep) pada soal ini. Hal ini diperkuat dengan persentase siswa yang menjawab salah mencapai $86 \%$ dengan rata-rata $C R I$ rendah $(<2,5)$. Begitu juga pada soal nomor 9 (konsep persamaan GLBB) siswa juga dikatakan tidak memahami konsep (tidak tahu konsep). Hal ini ditunjukkan dengan jumlah fraksi siwa yang menjawab benar (0,28 atau 28\%) lebih kecil dari fraksi siswa yang menjawab salah (0,72 atau $72 \%$ ), serta rata-rata $C R I$ jawaban salah rendah yaitu 0,66 .

Untuk soal nomor 10 (konsep persamaan GLBB) sama halnya dengan soal nomor 4, dan 5. Pada soal ini semua siswa dikatakan memahami konsep dengan baik karena fraksi siswa yang menjawab benar adalah 1,00 atau $100 \%$ dengan rata-rata $C R I$ jawaban benar tinggi yaitu 4,92. Pada soal nomor 11 (konsep penerapan GLBB) rata-rata CRI jawaban benar adalah 2,36 dan rata-rata $C R I$ jawaban salah adalah 4,40. Sedangkan fraksi siswa yang menjawab benar (0,33 atau 33\%) lebih kecil dari fraksi siswa menjawab salah (0,67 atau 67\%). Sehingga secara keseluruhan dapat dikatakan bahwa siswa mengalami miskonsepsi dengan rata-rata $C R I$ jawaban salah tinggi $(>2,5)$.

Untuk soal nomor 12 (konsep gerak vertikal ke atas) dapat disimpulkan bahwa secara keseluruhan siswa mengalami miskonsepsi. Hal ini disebabkan karena fraksi siswa yang menjawab salah $(0,86$ atau $86 \%)$ lebih besar dari fraksi siswa yang menjawab benar $(0,14$ atau 14\%) dengan rata-rata $C R I$ jawaban salah tinggi, yaitu 4,27. Pada soal nomor 13 dan 14 (konsep gerak jatuh bebas) dapat dikatakan semua siswa mengalami miskonsepsi. Hal ini Puplished at https://ojs.stkippgri-lubuklinggau.ac.id/index.php/SJPIF 
diperkuat dengan hasil analisis yang menunjukkan bahwa fraksi siswa yang menjawab salah untuk soal nomor 13 maupun 14 adalah 1,00 atau 100\%. Sedangkan rata-rata CRI jawaban salah untuk soal nomor 13, dan 14 tinggi, yaitu 4,74, dan 4,76. Pada soal ini, tidak ada siswa yang menjawab dengan benar untuk siswa yang memperoleh skor tertinggi, sedang, maupun skor terendah.

Dari hasil analis data tes pilihan ganda dengan reasoning terbuka yang berjumlah 14 soal dilengkapi $C R I$, soal yang menunjukkan miskonsepsi yang dialami oleh siswa adalah soal nomor 1, 2, 6, 11,12,13,14, sedangkan siswa memahami konsep dengan baik pada soal nomor $3,4,5,7,10$, serta soal yang tidak dipahami oleh siswa (tidak tahu konsep) adalah soal nomor 8, dan 9. Miskonsepsi yang dialami oleh siswa meliputi konsep jarak dan perpindahan, kelajuan rata-rata dan kecepatan rata-rata, persamaan GLBB, penerapan GLBB, gerak vertikal ke atas, dan gerak jatuh bebas.

Pada konsep jarak dan perpindahan (soal nomor 1), siswa mengalami miskonsepsi sebanyak 57\%. Miskonsepsi pada konsep jarak dan perpindahan terjadi kerena siswa menganggap bahwa pengertian jarak dan perpindahan adalah sama, sehingga siswa menggunakan persamaan matematis yang sama untuk mencari nilai jarak dan perpindahan. Selanjutnya, 33\% siswa menjawab dengan benar, serta alasan yang tepat mengenai konsep jarak dan perpindahan pada persamaan matematis untuk menentukan nilai jarak dan perpindahan.

Pada konsep kelajuan rata-rata dan kecepatan rata-rata (soal nomor 2), siswa mengalami miskonsepsi sebanyak 70\%. Miskonsepsi ini terjadi karena sebagian siswa menganggap bahwa persamaan matematis untuk menentukan nilai kecepatam rata-rata sama halnya dengan menentukan nilai kelajuan rata-rata, selain itu sebagian siswa juga belum memahami klasifikasi besaran untuk kecepatan rata-rata yang merupakan besaran vektor, dan kelajuan rata-rata yang merupakan besaran skalar.

Pada konsep persamaan GLBB (soal nomor 6), siswa mengalami miskonsepsi sebanyak $81 \%$. Miskonsepsi ini terjadi karena banyaknya siswa yang menganggap bahwa percepatan sebuah benda yang dilempar ke atas kemudian kembali lagi ke tanah, hanya mengalami perlambatan dan percepatan. Padahal, pada saat mencapai titik tertinggi benda akan berhenti dengan percepatan sama dengan nol.

Pada konsep penerapan GLBB (soal nomor 11), siswa yang mengalami miskonsepsi sebesar $67 \%$. Miskonsepsi ini terjadi karena siswa menganggap contoh dari gerak yang termasuk gerak lurus berubah beraturan dipercepat adalah gerak sebuah bola yang jatuh 
bebas ke bumi. Padahal, gerak sebuah bola (benda) yang menuruni bidang miring juga termasuk gerak lurus berubah beraturan yang dipercepat.

Pada konsep mengenai persamaan yang terdapat pada gerak vertikal ke atas (soal nomor 12), siswa yang mengalami miskonsepsi sebanyak 86\%. Miskonsepsi ini terjadi karena siswa menggunakan persamaan matematis yang salah dalam menentukan kecepatan awal suatu bola yang dilempar ke atas kemudian jatuh kembali ke tanah. Pada soal ini, besaran yang diketahui adalah selang waktu total yang dibutuhkan bola dari awal pelemparan hingga kembali lagi ke tanah. Persamaan yang kebanyakan siswa gunakan dalam menentukan kecepatan awal bola tersebut adalah $\mathrm{v}=\mathrm{Vo}+\mathrm{gt}$. Padahal untuk menentukan kecepatan awal bola pada saat pelemparan dapat menggunakan persamaan berikut.

$$
h=v_{0}+\frac{1}{2} g t^{2} \quad \text { dan } \quad v=\sqrt{2 g h}
$$

Pada konsep tentang gerak jatuh bebas (soal nomor 13), dapat dikatakan semua siswa (100\% siswa) mengalami miskonsepi. Miskonsepsi ini terjadi karena hampir semua siswa menjawab bahwa batu dan kertas yang menggumpal apabila gaya gesek udaranya diabaikan dan dijatuhkan ke lantai pada ketinggian dan waktu bersamaan, maka batu akan jatuh terlebih dahulu ke lantai. Alasan yang diberikan oleh siswa kebanyakan menganggap batu lebih dulu jatuh ke lantai karena massa batu lebih besar dari massa kertas yang menggumpal. Bahkan, sangat disayangkan karena masih terdapat siswa yang memberikan alasan bahwa massa batu lebih berat dari massa kertas yang menggumpal.

Pada soal nomor 14 yang juga merupakan konsep dari gerak jatuh bebas saling berkaitan dengan soal nomor 13. Pada soal nomor 14 siswa diminta untuk memberikan penjelasan mengenai faktor yang menentukan kecepatan benda yang dijatuhkan dari ketinggian tertentu. Sama halnya seperti pada soal nomor 13, pada soal ini semua siswa juga mengalami miskonsepsi, yang artinya 100\% siswa memiliki pemahaman yang keliru. Miskonsepsi ini disebabkan karena sebagian siswa menganggap bahwa kecepatan suatu benda yang jatuh dari ketinggian tertentu ditentukan oleh percepatan gravitasi bumi, dan massa benda. Selain itu, sebagian siswa lainnya beranggapan bahwa yang menentukan kecepatan benda yang jatuh dari ketingian tertentu adalah ketinggian benda, dan massa benda. Padahal, dari persamaan matematis untuk menentukan nilai kecepatan benda yang jatuh dari ketinggian tertentu pada gerak jatuh bebas telah menjelaskan apa saja yang mempengaruhi kecepatan benda tersebut, yaitu $v=\sqrt{2 g h}$. Dari persamaan ini diketahui bahwa yang menentukan kecepatan benda dari ketinggian tertentu adalah percepatan Puplished at https://ojs.stkippgri-lubuklinggau.ac.id/index.php/SJPIF 
gravitasi bumi (g) dan ketinggian benda $(\mathrm{h})$, bukanlah massa benda.

Hasil penelitian menunjukkan bahwa dari 14 soal yang diujikan, 7 soal menunjukkan miskonsepsi terjadi pada siswa, sehingga ini sangat mempengaruhi hasil belajarnya. Hal tersebut terlihat dari nilai yang diperoleh siswa masih banyak di bawah KKM dan standar ketuntasan yang ditetapkan oleh pihak sekolah. Dari 42 siswa, hanya 14\% siswa yang memiliki nilai di atas 70. Permasalahan ini sesuai dengan pernyataan yang dikemukakan oleh Klammer (dalam Nopviana, 2011), bahwa terhambatnya proses penerimaan dan asimilasi pengetahuan-pengetahuan baru dalam diri siswa dapat menghalangi keberhasilan siswa dalam proses belajar lebih lanjut, salah satu faktornya disebabkan oleh adanya misksonsepsi.

Miskonsepsi yang ditemukan pada penelitian ini menunjukkan konsep yang dimiliki oleh siswa tidak sesuai dengan konsep para ilmuwan. Miskonsepsi dalam penelitian ini seperti telah disebutkan terjadi diantaranya karena siswa keliru dalam memahami pengertian mengenai istilah-istilah yang ada pada konsep materi gerak. Hal ini berhubungan dengan pengalaman/pergaulan sosial, pengetahuan prasyarat yang kurang memadai dan faktor bahasa. Pengalaman yang dimaksudkan merupakan pengalaman yang dialami sendiri oleh siswa, seperti berinteraksi dengan benda disekitarnya. Menurut Tayubi (dalam Nopviana, 2011), pengalaman sehari-hari siswa ketika berinteraksi dengan alam sekitarnya tersebut, dapat memunculkan miskonsepsi pada dirinya. Selain itu, banyaknya persamaan matematis (rumus) dalam konsep ini juga menyebabkan miskonsepsi karena siswa bingung dalam memilih dan menentukan rumus mana yang akan digunakan untuk menyelesaikan sebuah soal hitungan.

Kesulitan siswa terkait konsep fisis dan matematis berakibat pada saat terjadi kesalahankesalahan dalam menyelesaikan soal-soal ujian dan menjadi penyebab tidak tercapainya hasil belajar siswa secara optimal. Zahra (2015) menyatakan bahwa miskonsepsi pada siswa yang muncul secara terus menerus dapat mengganggu pembentukan konsepsi ilmiah. Pembelajaran yang tidak memperhatikan miskonsepsi menyebabkan kesulitan belajar dan akhirnya akan mengakibatkan rendahnya prestasi belajar siswa. Pada akhirnya, bila tidak segera diperbaiki miskonsepsi tersebut akan menjadi hambatan bagi siswa pada proses pembelajaran lanjut (Wulandari, T. A., Prihandono, T., \& Maryani, M, 2018).

Menurut Gumay, \& Ali, (2019) dalam praktek pembelajaran fisika (IPA) di sekolah analisis konsepsi awal jarang dilakukan. Guru menganggap bahwa hal tersebut menyita 
banyak waktu, dan pada umumnya guru lebih memilih untuk langsung mengajarkan materi IPA agar pembelajaran tersampaikan semua pada waktu yang telah ditentukan. Padahal, bentuk tes multiple choice dengan reasoning terbuka dapat digunakan karena waktu yang diperlukan tidak terlalu banyak. Dalam kegiatan ini ditekankan pengungkapan gejala fisika yang mungkin tidak terpikirkan sebelumnya oleh siswa. Heriyanti, A., \& Gumay, O. P. U. (2018) mengatakan bahwa dengan cara seperti ini memungkinkan perhatian siswa lebih besar dan mereka berusaha menjelaskan gejala yang diamati itu sesuai dengan konsepsi mereka.

Penyebab terjadinya miskonsepsi pada siswa sendiri selain yang telah disebutkan juga sebelumnya, didukung pula dari pernyataan Suparno, yaitu miskonsepsi terjadi dapat berasal dari siswa itu sendiri, metode mengajar, buku teks yang digunakan dalam kelas, dan juga dari guru yang mengajar di kelas (Suparno, 2005). Oleh sebab itu perlu ada cara untuk mengatasi masalah yang yang terjadi pada siswa, seperti dengan mengungkapkan miskonsepsi tersebut, mencari peyebabnya dan mengambil tindakan yang sesuai terhadap miskonsepsi yang dialami siswa.

Disimpulkan bahwa, setiap siswa yang datang ke sekolah dan belajar fisika telah menyimpan berbagai konsep dibenaknya tentang obyek-obyek dan peristiwaperistiwa yang dialaminya. Miskonsepsi dapat terjadi disegala umur maupun tingkat kemampuan yang berbeda pada perempuan dan laki-laki. Secara garis besar miskonsepsi dapat diatasi dengan cara mencari atau mengungkap miskonsepsi yang dilakukan oleh siswa, mencoba menemukan penyebab miskonsepsi tersebut, dan mencari perlakuan yang sesuai untuk mengatasi.

\section{SIMPULAN}

Berdasarkan analisis data hasil penelitian mengenai miskonsepsi yang dialami oleh siswa kelas X SMA Negeri Terawas tahun pelajaran 2019/2020 pada materi gerak, dapat disimpulkan bahwa dari keseluruhan konsep materi gerak yang diujikan terdapat konsep-konsep dimana siswa cenderung mengalami miskonsepsi, yaitu pada konsep jarak dan perpindahan sebanyak 64\% (27 siswa), konsep kelajuan rata-rata dan kecepatan rata-rata sebanyak 70\% (30 siswa), konsep persamaan GLBB sebanyak 81\% (36 siswa), konsep penerapan GLBB sebanyak 68\% (28 siswa), konsep gerak vertikal ke atas sebanyak 86\% (36 siswa), dan konsep gerak jatuh bebas sebanyak 100\% (42 siswa). Tes gerak lurus yang berbentuk multiple choice dengan reasoning terbuka dan dilengkapi Certainty of Puplished at https://ojs.stkippgri-lubuklinggau.ac.id/index.php/SJPIF 
Response Index (CRI) dapat digunakan untuk mengidentifikasi siswa yang mengalami miskonsepsi, siswa yang memahami konsep, dan siswa yang tidak paham konsep. Dari 14 soal yang diberikan, 7 soal siswa mengalami miskonsepsi, 5 soal siswa memahami konsep dengan baik, dan 2 soal siswa tidak memahami konsep.

\section{DAFTAR PUSTAKA}

Gumay, O. P. U., \& Ali, M. (2019). Penerapan Model Picture and Picture pada Pembelajaran Fisika Kelas VII SMP Negeri Pasenan. Silampari Jurnal Pendidikan Ilmu Fisika, 1(1), 52-59.

Gumilar, S. (2016). Analisis Miskonsepsi Konsep Gaya Menggunakan Certainty of Respon Index (CRI). Gravity: Jurnal Ilmiah Penelitian Dan Pembelajaran Fisika, 2(1).

Hasan, S., Bagayoko, D., \& Kelley, E. L. (1999). Misconceptions and the certainty of response index (CRI). Physics education, 34(5), 294-299.

Heriyanti, A., \& Gumay, O. P. U. (2018). Penerapan Model Direct Instruction pada Pembelajaran Fisika. SPEJ (Science and Physic Education Journal), 2(1), 30-35.

Nopviana. (2011). Identifikasi Miskonsepsi Siswa Pada Pokok Bahasan Usaha dan Energi di SMA Srijaya Negara Palembang dengan Menggunakan CRI (Certainty of Response Index). Skripsi FKIP Unsri Inderalaya. Tidak diterbitkan.

Novitasari, F., Supriadi, B., \& Maryani, M. (2019). IDENTIFIKASI MISKONSEPSI MAHASISWA PROGRAM STUDI PENDIDIKAN FISIKA ANGKATAN 2018 UNIVERSITAS JEMBER PADA PEMAHAMAN KONSEP LISTRIK STATIS DAN DINAMIS. JURNAL PEMBELAJARAN FISIKA, 8(4), 222-225.

Suparno, P. (2005). Miskonsepsi dan Perubahan Konsep Dalam Pendidikan Fisika. Jakarta: Grasindo.

Suparno, P. (2013). Miskonsepsi dan Perubahan Konsep dalam Pendidikan Fisika.Jakarta: Gramedia Widiasarana Indonesia.

Suwarna, I. P. (2013). Analisis Miskonsepsi Siswa SMA Kelas X pada Mata Pelajaran Fisika melalui CRI (Certainty of Response Index) Termodifikasi.

Syuhendri, S. (2014). Konsepsi alternatif mahasiswa pada ranah mekanika: analisis untuk konsep impetus dan kecepatan benda jatuh. Jurnal Inovasi dan Pembelajaran Fisika, 1(1), 56-68.

Trisna, N., \& Ariani, T. (2019). Model direct instruction dengan teknik probing prompting: Dampak terhadap hasil belajar fisika siswa kelas X SMA Negeri 4 Lubuklinggau Tahun Pelajaran 2018/2019. Silampari Jurnal Pendidikan Ilmu Fisika, 1(1), 24-37.

Wulandari, T. A., Prihandono, T., \& Maryani, M. (2018). Analisis Miskonsepsi Siswa pada Materi Suhu dan Kalor di Kelas XI SMA Jember. FKIP e-PROCEEDING, 3(1), 135-139.

Zahra, N., Kamaluddin, K., \& Muslimin, M. (2015). Identifikasi Miskonsepsi Fisika Pada Siswa Sman Di Kota Palu. JPFT (Jurnal Pendidikan Fisika Tadulako Online), 3(3), 62-66. 